\title{
Natural Compounds for the Prevention and Treatment of Cardiovascular and Neurodegenerative Diseases
}

\author{
Rosalba Leuci $^{+}$(D), Leonardo Brunetti ${ }^{+}$(D), Viviana Poliseno $(D)$, Antonio Laghezza (D), Fulvio Loiodice, \\ Paolo Tortorella (D) and Luca Piemontese * (D)
}

Dipartimento di Farmacia-Scienze del Farmaco-University of Bari “Aldo Moro", Via E. Orabona 4, 70125 Bari, Italy; r.leuci6@studenti.uniba.it (R.L.); leonardo.brunetti@uniba.it (L.B.); v.poliseno1@studenti.uniba.it (V.P.); antonio.laghezza@uniba.it (A.L.); fulvio.loiodice@uniba.it (F.L.); paolo.tortorella@uniba.it (P.T.)

* Correspondence: luca.piemontese@uniba.it

t The two authors contributed equally to this work.

check for

updates

Citation: Leuci, R.; Brunetti, L.; Poliseno V.; Laghezza, A.; Loiodice, F.; Tortorella, P.; Piemontese, L. Natural Compounds for the Prevention and Treatment of Cardiovascular and Neurodegenerative Diseases. Foods 2021, 10, 29. https:// dx.doi.org/10.3390/foods10010029

Received: 24 November 2020 Accepted: 22 December 2020 Published: 24 December 2020

Publisher's Note: MDPI stays neutral with regard to jurisdictional claims in published maps and institutional affiliations.

Copyright: (c) 2020 by the authors. Licensee MDPI, Basel, Switzerland. This article is an open access article distributed under the terms and conditions of the Creative Commons Attribution (CC BY) license (https: / / creativecommons.org/ licenses/by/4.0/).

\begin{abstract}
Secondary metabolites from plants and fungi are stimulating growing interest in consumers and, consequently, in the food and supplement industries. The beneficial effects of these natural compounds are being thoroughly studied and there are frequent updates about the biological activities of old and new molecules isolated from plants and fungi. In this article, we present a review of the most recent literature regarding the recent discovery of secondary metabolites through isolation and structural elucidation, as well as the in vitro and/or in vivo evaluation of their biological effects. In particular, the possibility of using these bioactive molecules in the prevention and/or treatment of widely spread pathologies such as cardiovascular and neurodegenerative diseases is discussed.
\end{abstract}

Keywords: secondary metabolites; plants; fungi; food supplements; cardiovascular diseases; neurodegenerative diseases; Alzheimer's disease; metabolic syndrome

\section{Introduction}

Fungi and plants represent an important source of numerous bioactive compounds and have historically been used for medicinal purposes by virtually all human cultures [1].

Plants produce various secondary metabolites (SMs) in order to defend themselves from external attacks and as signals. These SMs show interesting biological and pharmacological activities: for this reason, they are often isolated and used for therapeutic purposes [2]. Plant-derived compounds are currently used in oncology therapy worldwide because they are considered less toxic and thus better accepted by patients [3], even if this consideration cannot be extended to all natural compounds and can be dangerous. Taxanes, used for the treatment of patients with breast cancer, are an excellent example of a valuable drug: paclitaxel is isolated from the bark of Taxus brevifolia (Pacific yew tree), while docetaxel is extracted from the needles of Taxus baccata (European yew tree) [4]. Other anticancer treatments obtained from plants are the vinca alkaloids vincristine and vinblastine, derived from the periwinkle plant Catharanthus roseus [5].

Polyphenols are another remarkable class of plant-derived SM, endowed with protective effects against pathologies such as cancer, cardiovascular diseases, diabetes, and neurodegenerative disorders [6]. These are classified into phenolic acids, flavonoids, stilbenes, coumarins, lignins, and tannins. Coumarins are found in a variety of plants such as tonka bean (Dipteryx odorata), sweet woodruff (Galium odoratum), sweet grass (Hierochloe odorata), deer-tongue (Dichanthelium clandestinum), vanilla grass (Anthoxanthum odoratum), mullein (Verbascum spp.), and sweet-clover (Melilotus sp.) [7]. Resveratrol, a stilbenoid present in many fresh fruits and plants such as Polygonum cuspidatum, Arachis hypogea, Cassia sp., Eucalyptus, Morus rubra, and Vitis vinifera, has been reported to have numerous biological properties, such as antioxidant, anti-inflammatory, anti-cancer, anti-aging, anti-obesity, anti-diabetes, cardioprotective and neuroprotective effects [8]. 
In recent years, the interest on the medicinal properties of compounds from Cannabis species has been steadily growing. More than 100 phyto-cannabinoids have been identified from C. sativa; among them, the most potent psychoactive activity is displayed by trans$\Delta^{9}$-tetrahydrocannabinol (THC). According to several studies, cannabis derivatives can be useful in conditions such as pain, anorexia-cachexia, skin pathologies, neurodegenerative diseases, epilepsy, sleep disorders and infections. However, legislation regarding these compounds is still ambiguous, insufficient, and plagued by controversies linked to their adverse effects and their consumption as recreational drugs [9,10].

Fungi also produce bioactive natural products that are exploited for pharmaceutical purposes. Fungal metabolites with clinical use include beta lactams, e.g., penicillins $\mathrm{G}$ and $\mathrm{V}$, statins, cholesterol-lowering blockbuster drugs, the immunosuppressant cyclosporin and the anti-migraine ergotamine [11]. Beta-lactams are the most widely used class of antibiotics that, with the discovery of penicillin, produced by the fungus Penicillium notatum, early in the twentieth century, marked a new era for the treatment of bacterial infections [12]. Cyclosporin is employed for the treatment of autoimmune diseases such as psoriasis; it is a peptide isolated from Tolypocladium inflatum [13].

Many natural compounds from fungi and plants are extensively used as food supplements for the treatment and prevention of neurodegenerative and cardiovascular diseases [14], showing the growing interest in this field of research. Among the best-selling products, monacolin K, a component of red yeast rice fermented with several patented Monascus purpureus strains, is a widely discussed case. Considering its chemical structure and biological activity [15], the use of the food supplement containing this bioactive compound should be more strictly regulated. This review focuses on another important aspect of research regarding natural compounds: the isolation of secondary metabolites of fungi and plants and their biological evaluation as potential useful compounds for neurodegenerative and cardiovascular disorders.

\section{Natural Compounds and Neurodegenerative Diseases}

The prevention and treatment of neurodegenerative diseases (NDs), such as Parkinson's disease (PD) and Alzheimer's disease (AD), is an important avenue of research due to the increasing occurrence of these pathologies in the rapidly aging world population. Their multifactorial nature complicates their diagnostic and therapeutic profile and only few drugs are available [16-18]. Lifestyle factors, including dietary habits, influence the development of NDs, further cementing the role of food-derived compounds such as plant SMs in the long-term physiological balance of the nervous system [19]. Table 1 summarizes the body of literature regarding plant and fungal SMs with potential activity toward NDs.

Table 1. Natural compounds and neurodegenerative diseases.

\begin{tabular}{|c|c|c|c|c|}
\hline Source & Bioactive Compounds & Effects & Main Activities & Ref. \\
\hline $\begin{array}{c}\text { Cetraria islandica } \mathrm{L} . \\
\text { Ach }\end{array}$ & Furmarprotocetraric acid & $\begin{array}{l}\text { Neuroprotective and } \\
\text { antioxidant activities }\end{array}$ & $\begin{array}{c}\text { Oxygen radical } \\
\text { absorbance capacity } \\
(\text { ORAC) } \\
5.07 \pm 0.43 \mu \mathrm{mol} \mathrm{TE} / \mathrm{mg}\end{array}$ & [20] \\
\hline Spongionella sp. & $\begin{array}{l}\text { Gracilin } \mathrm{A}, \mathrm{H}, \mathrm{K}, \mathrm{J}, \mathrm{L} \text {, and } \\
\text { tetrahydroaplysulphurin-1 }\end{array}$ & Neuroprotective activity & $\begin{array}{c}\text { (Caspase } 3 \text { inh.) } \\
3.88-4.04 \times 10^{3} \mathrm{RFU}\end{array}$ & [21] \\
\hline Lepidium meyenii & 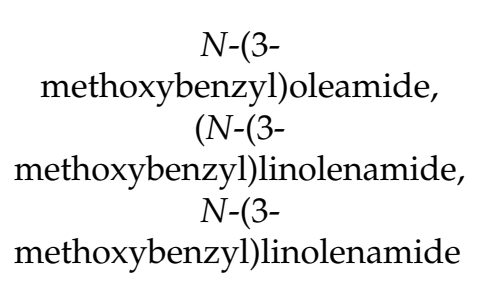 & $\begin{array}{l}\text { Neuroprotective activity, } \\
\text { peroxisome } \\
\text { proliferator-activated } \\
\text { receptor (PPAR) } \gamma \\
\text { interaction, inhibition of } \\
\text { fatty acid amide } \\
\text { hydrolase (FAAH) }\end{array}$ & $\begin{array}{c}\left.\text { (PPAR } \gamma \text { act., } \mathrm{EC}_{50}\right) \\
20.4-22.6 \mu \mathrm{M}\end{array}$ & [22] \\
\hline
\end{tabular}


Table 1. Cont.

\begin{tabular}{|c|c|c|c|c|}
\hline Source & Bioactive Compounds & Effects & Main Activities & Ref. \\
\hline $\begin{array}{l}\text { Aspergillus terreus } \\
\text { Y10 }\end{array}$ & $\begin{array}{c}\text { Asperteretal } F, G_{1}, G_{2}, H \text { and } \\
\text { others }\end{array}$ & $\begin{array}{l}\text { Inhibition of Tumor } \\
\text { Necrosis Factor } \alpha \\
(\mathrm{TNF} \alpha)\end{array}$ & $\begin{array}{l}\left(\mathrm{TNF} \alpha \text { inh., } \mathrm{IC}_{50}\right) \\
7.69 .9 \mu \mathrm{M}\end{array}$ & [23] \\
\hline Sarcophyton glaucum & Sarcophytolide & $\begin{array}{l}\text { Antimicrobic and } \\
\text { cytoprotective activities }\end{array}$ & $\begin{array}{c}\text { (MIC) } \\
0.13-0.22 \mu \mathrm{g} / \mathrm{mL}\end{array}$ & [24] \\
\hline $\begin{array}{l}\text { Hericius erinaceus and } \\
\text { Hericius flagellum }\end{array}$ & $\begin{array}{c}\text { Erinacine } \mathrm{A}, \mathrm{B}, \mathrm{C}, \mathrm{E}, \mathrm{F} \text {, and } \\
\text { others }\end{array}$ & Neurotrophic activity & $\begin{array}{c}\text { (increased NGF } \\
\text { expression) } \\
0.8-12 \mu \mathrm{g} / \mathrm{mL}\end{array}$ & [25] \\
\hline Narcissus tazetta L. & $\begin{array}{l}\text { (-)-9-O- } \\
\text { methylpseudolycorine, } \\
(-) \text {-narcissidine, } \\
(-) \text {-pancratinine-C, } \\
(+)-9-O-d e m e t h y l-2-a- \\
\text { hydroxyhomolycorine }\end{array}$ & $\begin{array}{c}\text { Inhibition of } \\
\text { acetylcholine esterase } \\
\text { AChE and } \\
\text { butyrylcholine esterase } \\
\text { (BChE) }\end{array}$ & $\begin{array}{c}\left(\mathrm{AChE} \text { inh, } \mathrm{IC}_{50}\right) \\
0.67-32.51 \mu \mathrm{M}\end{array}$ & [26] \\
\hline $\begin{array}{l}\text { Embelia ribes and } \\
\text { others }\end{array}$ & Embelin and others & $\begin{array}{c}\text { Inhibition of AChE, } \\
\text { BChE and Beta-secretase } \\
1 \text { (BACE-1); induction of } \\
\text { P-glycoprotein } 1 \text { (P-gp) }\end{array}$ & $\begin{array}{c}\left(\mathrm{AChE} \text { inh, } \mathrm{IC}_{50}\right) \\
2.50-6.98 \mu \mathrm{M}\end{array}$ & [27] \\
\hline Rumex abyssinicus & $\begin{array}{l}\text { Helminthosporin, emodin, } \\
\text { chryso-phanol, physcion }\end{array}$ & $\begin{array}{l}\text { Inhibition of } \mathrm{AChE} \\
\text { and } \mathrm{BChE}\end{array}$ & $\begin{array}{c}\left(\mathrm{AChE} \text { inh, } \mathrm{IC}_{50}\right) \\
2.63-33.7 \mu \mathrm{M}\end{array}$ & [28] \\
\hline Oxalis corniculate L. & Flavonoids 1-9 & $\begin{array}{l}\text { Inhibition of AChE, } \\
\text { BChE and carbonic } \\
\text { anhydrases II (CA-II) }\end{array}$ & $\begin{array}{c}\left(\mathrm{AChE} \text { inh, } \mathrm{IC}_{50}\right) \\
49.52-109.55 \mu \mathrm{g} / \mathrm{mL}\end{array}$ & [29] \\
\hline Lichens & $\begin{array}{l}\text { Atranorin, perlatolic acid, } \\
\text { physodic acid, usnic acid } \\
\text { and others }\end{array}$ & $\begin{array}{l}\text { Neurotrophic activity } \\
\text { and AChE inhibition }\end{array}$ & $\begin{array}{c}\left(\mathrm{AChE} \text { inh, } \mathrm{IC}_{50}\right) \\
6.8-27.1 \mu \mathrm{M}\end{array}$ & [30] \\
\hline Fungi and plants & $\begin{array}{l}\text { Tenuazonic acid, } \\
\text { epi-racidinol, mycophenolic } \\
\text { acid, radicinin, visoltricin, } \\
\text { 6-methoxymellein }\end{array}$ & $\begin{array}{l}\text { Inhibition of AChE, } \\
\text { BChE and } \\
\text { A } \beta \text {-aggregation; } \\
\text { antioxidant activity, } \\
\text { metal chelation }\end{array}$ & $\begin{array}{c}\left(\mathrm{AChE} \text { inh, } \mathrm{IC}_{50}\right) \\
6.86-11.4 \mu \mathrm{M}\end{array}$ & [31] \\
\hline S. flavescens & $(-)$-maackian and others & $\begin{array}{c}\text { Inhibition of } \\
\text { monoamine oxidases } \\
\text { (MAOs) }\end{array}$ & $\begin{array}{c}\left.\text { (MAO-B inh, } \mathrm{IC}_{50}\right) \\
0.68-52.3 \mu \mathrm{M}\end{array}$ & [32] \\
\hline Renealmia Alpinia & $\begin{array}{l}\text { Desmethoxyangonin } \\
\text { and others }\end{array}$ & Inhibition of MAOs & $\begin{array}{l}\text { (MAO-B inh, Ki) } \\
\text { 31-110 nM }\end{array}$ & [33] \\
\hline Ginkgo biloba & $\begin{array}{l}\text { Ginkgolic acid and } \\
\text { anacardic acid }\end{array}$ & $\begin{array}{c}\text { Decreased accumulation } \\
\text { of } \alpha \text {-synuclein }(\alpha \mathrm{SN}) \\
\text { aggregates }\end{array}$ & $\begin{array}{c}(\alpha \mathrm{SN} \text { aggr inh) } \\
10-100 \mu \mathrm{M}\end{array}$ & [34] \\
\hline $\begin{array}{l}\text { Ampelopsis } \\
\text { grossedentata }\end{array}$ & Dihydromyricetin & $\begin{array}{l}\text { Neuroprotective activity } \\
\text { and inhibition of } \alpha \mathrm{SN} \\
\text { fibril formation }\end{array}$ & $\begin{array}{c}(\alpha \mathrm{SN} \text { aggr inh) } \\
50-100 \mu \mathrm{M}\end{array}$ & [35] \\
\hline
\end{tabular}

Oxidative stress and neuroinflammation are considered two of the causes of NDs $[19,36]$. For this reason, neuroprotective agents targeting these pathological factors can be useful for the prevention and treatment of these disorders [36]. In recent years, several natural compounds have been explored for their neuroprotective and antioxidant activity. For example, polyphenols, which are secondary metabolites of plants present in 
various food and drinks, have shown important antioxidant properties [37]. However, numerous studies in the recent past have been focused on different and more original matrices.

Cetraria islandica L. Ach (or Iceland moss), as an example, is the most famous cetrarioid lichen species. It has been used for the treatment of various inflammatory diseases, and recently the neuroprotective properties of its major metabolite, fumarprotocetraric acid (FUM) were evaluated on neuron-like SH-SY5Y cells and glial U373-MG cells. FUM revealed different activities, acting as a scavenger of peroxyl radicals, decreasing reactive oxygen species (ROS) production, reducing GSH depletion and increasing the ratio of reduced glutathioneto oxidized glutathione (GSH/GSSG ratio). Moreover, FUM decreased mitochondrial $\mathrm{Ca}^{2+}$ levels, protected the mitochondrial membrane against $\mathrm{H}_{2} \mathrm{O}_{2}$ induced damage, suppressed $\mathrm{H}_{2} \mathrm{O}_{2}$-induced expression of protease caspase-3, decreased pro-apoptotic factor Bax levels and increased the anti-apoptotic Bcl-2 levels [20].

Another interesting research is the in vitro screening of the antioxidant action of six diterpene derivatives, named Gracilin $\mathrm{A}, \mathrm{H}, \mathrm{K}, \mathrm{J}, \mathrm{L}$, and tetrahydroaplysulphurin-1, isolated from Spongionella sp., a marine sponge. The two parameters for the evaluation of antioxidant activity were MTT (3-(4,5-dimethylthiazol-2-yl)-2,5-diphenyltetrazolium bromide) assay and LDH levels: the first is correlated with mitochondrial function, the second is a cytoplasmic enzyme released in the culture medium following cell membrane damage. The tested compounds showed significant neuroprotective activity, interacting with targets such as mitochondrial oxidative phosphorylation and kinases involved in apoptosis [21].

Looking at innovative targets, a recent paper describes Macamides, a group of secondary metabolites isolated from the plant Lepidium meyenii (Maca). These compounds are benzylamides of fatty acids, active as analogues of the endocannabinoid anandamide (AEA) and studies have demonstrated that they inhibit fatty acid amide hydrolase (FAAH), blocking AEA hydrolysis. Gugnani et al. demonstrated a neuroprotective role of macamides in vitro and in vivo. Macamides reduced $\mathrm{Mn}$-induced mitochondrial toxicity in glioblastoma U-87 MG cells, probably by binding the $\mathrm{CB}_{1}$ receptor, and it could thus be useful in the treatment of neurodegenerative diseases, especially Alzheimer's Disease. Like AEA, macamides can interact with PPAR $\gamma$, regulating inflammation, energetic metabolism and glucose homeostasis, all important factors for the prevention of $\mathrm{AD}[22,38]$.

Other interesting bioactive secondary metabolites are butenolides, from the fungus Aspergillus terreus. The chemical structures of these compounds were recently elucidated and their effects against the expression of TNF $\alpha$ in lipopolysaccharide (LPS)-activated BV2 microglia cells were tested. The most promising compound was asperteretal $\mathrm{F}$, which inhibited the expression of TNF $\alpha$ in a dose-dependent mode, making it an anti-neuroinflammatory candidate for the treatment of NDs [23].

Sarcophytolide, instead, is a lacton cembrane diterpene derived from soft coral Sarcophyton glaucum that was recently shown to possess antimicrobic activity towards Staphylococcus aureus, Pseudomonas aeruginosa, and Saccharomyces cerevisiae. Moreover, pretreatment of primary cortical cells with sarcophytolide had a strong cytoprotective effect against glutamate-induced neurotoxicity and increased the expression of Bcl-2. This mechanism confirmed by evidence that sarcophytolide showed a cytoprotective activity only if added before and not after the exposure of neuronal cells to glutamate [24].

Meanwhile, Rupcic et al. discovered two new metabolites of the medicinal mushrooms Hericius erinaceus and Hericius flagellum (a rare species). They determined the chemical structures of these new compounds and of other metabolites previously isolated from the two species through Nuclear Magnetic Resonance (NMR) and High-Resolution Mass Spectroscopy (HRMS), identifying them as cyathane diterpenes. All these compounds were tested in vitro on PC12 cells for their neurotrophic activity, showing that, although none of them was endowed with intrinsic neurotrophic properties, all of them promoted the production of neurotrophins NGF (Nerve Growth Factor) and BDNF (Brain-Derived Neurotrophic Factor) in astrocytic cells [25]. 


\subsection{Alzheimer's Disease}

Alzheimer's disease (AD) is the most common neurodegenerative disorder, characterized by several cognitive and behavioral disfunctions, and it affects mainly old people, although rare early onset of this disease is also known $[39,40]$. Several hypotheses have been formulated regarding its pathogenesis, including deposition of amyloid $\beta(A \beta)$, damaged cholinergic transmission, oxidative stress and hyperphosphorylated Tau aggregation $[41,42]$.

According to the so-called "cholinergic hypothesis", AD is linked to decreased levels of acetylcholine (ACh) accompanied by a loss of cholinergic neurons in the central nervous system. In order to raise the concentration of this neurotransmitter, inhibitors of acetylcholine esterase (AChE), the main enzyme responsible for the degradation of $\mathrm{ACh}$, have found use in clinical practice, improving functional autonomy and cognitive functions in $\mathrm{AD}$ patients [43]. Among these drugs are natural compounds such as galantamine, the most important Amaryllidaceae alkaloid [44]. For this reason, the potential use in AD of other Amaryllidaceae alkaloids, isolated from Narcissus tazetta L., was recently evaluated. Their structures were determined by NMR and mass spectroscopy, while in vitro AChE and butyrylcholinesterase (BChE) inhibitory activity was evaluated using Ellman's colorimetric method, with galantamine as reference. (+)-11-Hydroxygalanthine had the highest selective inhibitory activity on $\mathrm{AChE}$, and narcissidine also inhibited $\mathrm{AChE}$ rather than $\mathrm{BChE}$; while (-)-pancratinine-C was a selective BChE inhibitor. Docking studies confirmed bioactivity results [26].

The screening of libraries of natural compounds has also proven to be a promising strategy to identify multi-target compounds for the treatment of AD. Embelin, a 1,4-benzoquinone isolated from Embelia ribes fruits, recently emerged from one such screening, showing inhibitory activity towards $\mathrm{AChE}, \mathrm{BChE}$ and beta-secretase 1 (BACE-1, involved in the deposition of $A \beta$ ). Another two natural products present in the library, L-tetrahydropalmatine and papaverine, exhibited a good inhibition of AChE. Moreover, embelin, in LS-180 cells, acted as an inductor of P-gp, an ATP-dependent efflux pump situated in the blood-brain barrier (BBB) whose decreased levels can lead to the accumulation of $\mathrm{A} \beta$ plaques [27].

Anti-AChE activity was exhibited also by four secondary metabolites (helminthosporin, emodin, chrysophanol, and physcion) of the African medicinal plant Rumex Abyssinias. These compounds, sharing an anthraquinone structure, were isolated and showed significant AChE inhibitory activity. Helminthosporin also displayed activity as a non-competitive $\mathrm{BChE}$ inhibitor, while the other compounds were only weakly active against this target. Moreover, the tricyclic flat structure makes helminthosporin lipophilic enough to cross the $\mathrm{BBB}$, balancing its low LogP value [28].

Biologically active secondary metabolites such as phenols, alkaloids flavonoids, terpenes, sterols, and tannins from the ethanolic extract of Oxalis corniculata L. are endowed with carbonic anhydrase and cholinesterase inhibitory activity, with potential uses against epilepsy and Alzheimer's disease, respectively. Moreover, nine flavonoids were isolated from chloroform and ethyl acetate fractions, displaying ChEs and carbonic anhydrase II (CA-II) inhibitory activity [29].

Lichens have also been used as a source of natural compounds for the treatment of $\mathrm{AD}$. During a recent study conducted on murine neuroblastoma Neuro2A cells, lichen-derived secondary metabolites (atranorin, perlatolic acid, physodic acid and usnic acid) displayed an important increase in neurite outgrowth, with perlatolic acid achieving better results than reference compound resveratrol. MTT assays revealed that only usnic acid showed cytotoxicity at neurotrophic doses. The molecular mediators of these effects are NGF, which is upregulated by atranorin, perlatolic acid and physodic acid, and BDNF, which is upregulated by atranorin and physodic acid. Only perlatolic acid had a potential inhibitory activity on $\mathrm{AChE}$, at a concentration that was comparable with galantamine and lower than biroquinone, another lichen metabolite reported as AChE inhibitor [30]. 
Detailed knowledge of the structure of plant and fungal secondary metabolites has also proven useful directing screening activities. Due to their similarity to existing nuclei used in AChE inhibitors and metal chelators, fungal secondary metabolites tenuazonic acid (TA), epi-radicinol (ROH), mycophenolic acid (MA), radicinin (RAD), visoltricin/fungerin (FU) and plant metabolite 6-methoxymellein (6-MM) were screened for various activities such as inhibition of $\mathrm{AChE}, \mathrm{BChE}$ and $\mathrm{A} \beta$-aggregation, antioxidant effect and $\mathrm{Cu}$ and $\mathrm{Zn}$ interaction. A preliminary UV spectrophotometry test for metal chelation of $\mathrm{Cu}$ (II) and $\mathrm{Zn}$ (II) at physiological $\mathrm{pH}$ revealed that TA, MA and 6-MM probably interacted with $\mathrm{Cu}$ (II). TA and $\mathrm{ROH}$ exhibited a significant selective AChE inhibitory activity, while FU was the only compound that inhibited BChE. 2,2-diphenyl-1-picrylhydrazyl (DPPH) radical scavenging activity assay suggested that TA and MA behaved as antioxidants. Moreover, all molecules were inhibitors of $A \beta_{1-40}$ aggregation, as demonstrated by spectrofluorimetric assays, with $\mathrm{ROH}$ being the most active compound [31].

\subsection{Parkinson's Disease}

Parkinson's disease (PD) is a very common neurodegenerative disease characterized by motor symptoms, such as rigidity, bradykinesia and tremor, and non-motor symptoms, including sleep disorders and cognitive abnormalities [45]. The principal causes of this pathology are the depletion of dopamine in nerve terminals to the striatum and the progressive degeneration of dopaminergic neurons in the substantia nigra [46]. The therapy involves the use of levodopa associated with an inhibitor of the peripheral metabolism of levodopa, for example carbidopa. Additionally, other drugs can be administrated, such as dopaminergic agonists, monoamine oxidase-B inhibitors and catechol O-methyltransferase inhibitors [47].

Monoamine oxidases (MAOs) are enzymes responsible for the oxidative deamination of both xenobiotic and endogenous neurotransmitters. Both MAO isoforms (MAO-A and $\mathrm{MAO}-\mathrm{B})$ are involved in the degradation of dopamine; however, MAO-B is the predominant isoform in the human brain. For this reason, MAO-B selective inhibitors, like selegiline and rasagiline, are used for the treatment of $\mathrm{PD}$, raising striatal dopaminergic activity through the inhibition of dopamine metabolism [48-50].

In recent years, many natural inhibitors of MAO-B have been discovered and characterized, representing a powerful source of inspiration for further drug development [51].

MAO-A and MAO-B inhibitory activities of seven compounds isolated from the extract of S.flavescens were recently investigated, highlighting (-)-maackian as a potent inhibitor of MAO-B and as a candidate for the development of drugs for Parkinson's disease. The structurally related compound (-)-4-hydroxy-3-methoxy-8,9-methylenedioxypterocarpan was a non-selective inhibitor of both isoforms, as well as formononetin and genistein. Sophora-flavanone B weakly inhibited MAO-A, but not MAO-B, while kushenol F showed a good inhibitory activity on MAO-A and a weak one on MAO-B [32].

A dichloromethane extract of Renealmia Alpinia, was recently shown to possess a potent inhibitory activity towards both MAO-A and MAO-B. From this extract, desmethoxyangonin, a kavalactone, was isolated. It exhibited a potent, selective and competitive inhibition of MAO-B rather than MAO-A, confirmed by molecular modeling studies, leading to its selection as a candidate for further drug development. Other isolated molecules from the extract displayed moderate inhibition of both isoforms [33].

The aggregation of $\alpha$-synuclein $(\alpha \mathrm{SN})$ in cytoplasmic inclusions called Lewy bodies is another important pathogenetic mechanism involved in PD. The formation of $\alpha \mathrm{SN}$ fibrils leads to the disruption of synaptic homeostasis and neurodegeneration. While the exact mechanism is not clear, $\alpha \mathrm{SN}$ is an interesting target for natural and synthetic drugs alike $[52,53]$.

A natural compound extracted from Ginkgo biloba leaves, ginkgolic acid (GA), and its related molecule anacardic acid (AA) were screened for their influence on $\alpha \mathrm{SN}$ aggregates. The treatment of $\mathrm{KCl}$-depolarized SH-SY5Y neuroblastoma cells with GA and AA led to a progressive and relevant decrease in $\alpha \mathrm{SN}$-positive aggregates, probably also due to 
increased activation of macro-autophagy, that resulted in increased survival of the neural cells [34]. It should be noted that extracts from this plant, containing as low as $5 \mathrm{mg} / \mathrm{kg}$ GA, still showed potential to improve cognitive function in mild dementia patients after $>24$ weeks administration at a dosage of $240 \mathrm{mg}$ /day [54]. Dihydromyricetin (DHM) is a flavonoid isolated from Ampelopsis grossedentata, a herb used in traditional Chinese medicine. Previous studies demonstrated that this compound played a neuroprotective role, and DHM, as proved by MTT assays on PC12 cells, blocked $\alpha \mathrm{SN}$ fibrillo-genesis and its cytotoxicity. Moreover, DHM also disassembled preformed $\alpha \mathrm{SN}$ fibrils, making it a potential molecule for the therapy of PD [35].

\section{Metabolic Syndrome and Cardiovascular Risk}

Metabolic syndrome (MS) is an increasingly prevalent condition that comprises a variety of pathological states, ranging from type 2 diabetes mellitus (T2DM) to obesity, hyperlipidemia and hypertension [55]. Obesity and hyperlipidemia are known causes of hyperinflammatory states, leading to the expression of pro-inflammatory cytokines and to reduced levels of nitric oxide (NO, which regulates endothelial homeostasis). Moreover, insulin-resistance leads to a blocking of the vasodilating effects of insulin itself, causing endothelial dysfunction. All these factors increase cardiovascular risk [56] and contribute significantly to the morbidity and mortality of cardiovascular diseases (CVD), the most prevalent cause of death worldwide.

Unfortunately, available drugs for the treatment of metabolic disorders are few and sometimes expensive: for this reason, researchers are focusing on the discovery of new and effective drugs $[57,58]$. In the last decade, it has become clear that an approach covering all underlying pathological conditions is required for the therapy of metabolic syndrome. Although the first step in such a therapeutic regime consists of increased physical exercise and dietary intervention, in many cases pharmacological action is necessary [59].

Over the years, the different aspects of metabolic syndrome have been thoroughly studied, and a number of potential molecular targets have been identified and characterized. Peroxisome Proliferator-Activated Receptors (PPARs), a family of nuclear receptors involved in all aspects of energetic metabolism, have attracted much interest as targets for therapy, considering their important role in the recent past in the treatment of both dyslipidemic and glucose-related pathologies [60,61]. Three PPAR receptor subtypes have been identified to date, respectively PPAR $\alpha$, PPAR $\gamma$ and PPAR $\delta$, each of which binds different endogenous ligands and is selectively expressed in different organs and tissues [62-64]. Their differential expression and ligand specificity mirror their different physiological roles: PPAR $\alpha$ and PPAR $\delta$ are mostly responsible for catabolic functions such as lipid oxygenation and glucose consumption, while PPAR $\gamma$ regulates glucose uptake and anabolic functions, particularly lipid storage and adipose tissue formation [65].

An enhanced understanding of the pharmacological profile of PPAR agonists has led to increased interest in their development, focusing particularly on obtaining a selective modulation of their subtypes, in order to maximize their beneficial effects and to minimize adverse reactions [66-69]. This focus on PPAR agonists is, however, not exclusive to medicinal chemists, and PPAR agonism or related activities have been reported for various secondary metabolites derived from plant and fungal extracts.

Table 2 summarizes the body of literature regarding plant and fungal SMs with potential activity toward MS and CVD. 
Table 2. Natural compounds with potential use in the therapy of metabolic syndrome and/or with additional effects for the reduction of cardiovascular risk.

\begin{tabular}{|c|c|c|c|c|}
\hline Source & Bioactive Compounds & Effects & Main Activities & Ref. \\
\hline Acalypha fluticosa & $\begin{array}{c}\text { 2-methyl-5,7- } \\
\text { dihydroxychromone } \\
\text { 5-O-b-D-glucopyranosid, } \\
\text { acalyphin, apigenin, and } \\
\text { Kaempferol 3-O-rutinoside } \\
\text { and an acetylated derivate of } \\
\text { chromone glucoside }\end{array}$ & $\begin{array}{l}\text { Agonism of PPAR } \alpha \\
\text { and PPAR } \gamma ; \\
\text { anti-inflammatory } \\
\text { properties }\end{array}$ & $\begin{array}{c}\text { (PPAR } \alpha \text { act., } \mathrm{FI}) \\
1.16-2.25 \text { at } 50 \mu \mathrm{M}\end{array}$ & {$[70]$} \\
\hline Talisia nervosa Radlk & $\begin{array}{c}\text { (-)-catechin, methyl gallate, } \\
\text { ethyl gallate, and } \\
\beta \text {-D-glucopyranose,1,4,6- } \\
\text { tris }(3,4,5- \\
\text { trihydroxybenzoate) }\end{array}$ & $\begin{array}{l}\text { Agonism of PPAR } \alpha, \\
\text { PPAR } \gamma \text { and liver X } \\
\text { receptor (LXR); reduction } \\
\text { of NO production }\end{array}$ & $\begin{array}{c}\text { (PPAR } \gamma \text { act., } \mathrm{FI}) \\
1.85-3.02 \text { at } 50 \mu \mathrm{M}\end{array}$ & {$[71]$} \\
\hline $\begin{array}{c}\text { Penicillium } \\
\text { chrysogenum J08NF-4 }\end{array}$ & $\begin{array}{l}\text { A new bile acid } \\
\text { trifluoroacetate }\end{array}$ & $\begin{array}{l}\text { Agonism of PPAR } \gamma, \\
\text { anti-inflammatory } \\
\text { properties }\end{array}$ & $\begin{array}{l}\text { (PPAR } \gamma \text { act., } \mathrm{FI}) \\
2.0 \text { at } 50 \mu \mathrm{M}\end{array}$ & {$[72]$} \\
\hline $\begin{array}{l}\text { Cyanobium sp. } \\
\text { LEGE } 07,175 \text { and } \\
\text { Nodosilinea sp. } \\
\text { LEGE } 06001\end{array}$ & $\begin{array}{l}13^{2} \text {-hydroxy-pheopytin a and } \\
13^{2} \text {-hydroxy-pheofarnesin a }\end{array}$ & $\begin{array}{l}\text { Increase of PPAR } \gamma \\
\text { mRNA expression }\end{array}$ & $\begin{array}{l}\text { (Lipid-reducing } \\
\text { Activity, } \mathrm{EC}_{50} \text { ) } \\
8.9-15.5 \mu \mathrm{M}\end{array}$ & [73] \\
\hline $\begin{array}{l}\text { Penicillium expansum } \\
\text { Y32 }\end{array}$ & $\begin{array}{c}\text { Communesin A, B, I, } \\
\text { fumiquinazoline Q, } \\
\text { protuboxepin A, B, E, and } \\
\text { others }\end{array}$ & $\begin{array}{l}\text { Mitigation of bradycardia, } \\
\text { vasculo-genetic effect }\end{array}$ & $\begin{array}{l}\text { (Acid } \\
\text { sphingomyelinase } \\
\text { mitigation) } \\
20-100 \mu \mathrm{M}\end{array}$ & {$[58]$} \\
\hline Lichens & $\begin{array}{l}\text { Thirty-seven secondary } \\
\text { metabolites and } \\
\text { semisynthetic derivates }\end{array}$ & $\begin{array}{l}\text { Anti-AGE activity, } \\
\text { vasodilation }\end{array}$ & $\begin{array}{c}\text { (Pentosidine-like } \\
\text { AGEs formation, } \\
\text { IC }_{50} \text { ) } \\
0.08-0.70 \mathrm{mM}\end{array}$ & {$[74]$} \\
\hline Schisandra chinensis & $\begin{array}{l}\text { Acidic polysaccharide } \\
\text { (SCAP) }\end{array}$ & $\begin{array}{l}\text { Anti-diabetic and } \\
\text { anti-apoptotic role }\end{array}$ & $\begin{array}{c}\left(\mathrm{H}_{2} \mathrm{O}_{2} \text {-induced }\right. \\
\text { apoptosis inh }) \\
15.6-62.5 \mu \mathrm{M} \\
\end{array}$ & {$[75]$} \\
\hline Sesbania grandiflora & $\begin{array}{l}\text { Quercetin, kaempferol, } \\
\text { vomifoliol, loliolide } \\
\text { and others }\end{array}$ & $\begin{array}{l}\text { Inhibition of } \alpha \text {-amylase } \\
\text { and } \alpha \text {-glucosidase; } \\
\text { antioxidant activity }\end{array}$ & $\begin{array}{c}\text { ( } \alpha \text {-Glucosidase inh, } \\
\left.\text { IC }_{50}\right) \\
17.45-388.48 \mu \mathrm{M}\end{array}$ & {$[76]$} \\
\hline Cassia bakeriana craib & $\begin{array}{l}\text { Kaempeferol-3-O- } \\
\text { rhamnoside and } \\
\text { kaempferol }\end{array}$ & $\begin{array}{l}\text { Inhibition of } \alpha \text {-amylase } \\
\text { and antioxidant activity }\end{array}$ & $\begin{array}{l}\text { ( } \alpha \text {-Glucosidase inh, } \\
\left.\mathrm{IC}_{50}\right) \\
0.36-0.61 \mathrm{mg} / \mathrm{mL}\end{array}$ & {$[77]$} \\
\hline $\begin{array}{c}\text { Ocimum } \\
\text { campechianum Mill. }\end{array}$ & $\begin{array}{l}\text { Methyl rosmarinate, } \\
\text { rosmarinic acid, 5-demethyl } \\
\text { nobiletin, 5-demethyl } \\
\text { sinensetin, luteolin }\end{array}$ & $\begin{array}{c}\text { Inhibition of } \\
\alpha \text {-glucosidase, } \\
\text { antihyperglycemic action }\end{array}$ & $\begin{array}{c}\text { ( } \alpha \text {-Glucosidase inh) } \\
12.86-82.77 \% \text { at } \\
0.75 \mathrm{mM}\end{array}$ & {$[78]$} \\
\hline $\begin{array}{l}\text { Aspergillus terreus } \\
\text { MC751 }\end{array}$ & $\begin{array}{l}\text { Butyrolactone I and II, three } \\
\text { acetylated derivates of } \\
\text { butyrolactone I }\end{array}$ & $\begin{array}{c}\text { Inhibition of } \\
\alpha \text {-glucosidase, } \\
\text { antioxidant activity }\end{array}$ & $\begin{array}{l}\text { ( } \alpha \text {-Glucosidase inh, } \\
\left.\text { IC }_{50}\right) \\
52.17-175.18 \mu \mathrm{M}\end{array}$ & [79] \\
\hline Ganoderma australe & Stella-steroid & $\begin{array}{c}\text { Inhibition of } \\
\alpha \text {-glucosidase and } \\
\text { Dipeptidyl peptidase } 4 \\
\text { (DPP-4) }\end{array}$ & $\begin{array}{c}\text { ( } \alpha \text {-Glucosidase inh, } \\
\left.\text { IC }_{50}\right) \\
314.54 \mu \mathrm{M}\end{array}$ & {$[80]$} \\
\hline
\end{tabular}


Table 2. Cont.

\begin{tabular}{|c|c|c|c|c|}
\hline Source & Bioactive Compounds & Effects & Main Activities & Ref. \\
\hline Aspergillus sydowii & Asperentin B & $\begin{array}{c}\text { Inhibition of } \\
\text { Protein-tyrosine } \\
\text { phosphatase 1B (PTP1B) }\end{array}$ & $\begin{array}{l}\left(\mathrm{PTP}_{\mathrm{B}} \mathrm{inh}, \mathrm{IC}_{50}\right) \\
\quad 2.05 \mu \mathrm{M}\end{array}$ & {$[81]$} \\
\hline Moringa oleifera & $\begin{array}{l}\text { Two sulfur-contained } \\
\text { compounds }\end{array}$ & Anti-adipogenic activity & $\begin{array}{l}\text { (Lipid accumulation, } \\
\text { inh, } \mathrm{IC}_{50} \text { ) } \\
29.6 \mu \mathrm{M}\end{array}$ & {$[82]$} \\
\hline Allium satioum $\mathrm{L}$. & $\begin{array}{c}\text { Three eugenol diglycosides } \\
\text { and three } \beta \text {-carboline } \\
\text { alkaloids }\end{array}$ & $\begin{array}{l}\text { Inhibition of adipogenesis } \\
\text { and lipid accumulation }\end{array}$ & $\begin{array}{c}\text { (Lipid accumulation, } \\
\text { inh) } \\
\text { active at } 20 \mu \mathrm{M}\end{array}$ & [83] \\
\hline Curcuma amada & $\begin{array}{l}\text { Two natural labdane } \\
\text { diterpenes and one drimane } \\
\text { sesquiterpene }\end{array}$ & $\begin{array}{c}\text { Inhibition of lipase and } \\
\alpha \text {-glucosidase }\end{array}$ & $\begin{array}{l}\left.\text { (Lipase inh, } \mathrm{IC}_{50}\right) \\
6.1-665.9 \mu \mathrm{M}\end{array}$ & {$[84]$} \\
\hline Magnolia spp. & Honokiol & $\begin{array}{l}\text { Inhibition of Histone } \\
\text { deacetylase (HDAC)- } \\
\text { mediated cystathionine } \\
\gamma \text {-lyase degradation }\end{array}$ & $\begin{array}{l}\text { (HDAC6 inh) } \\
\text { active at } 5 \mu \mathrm{M}\end{array}$ & {$[85]$} \\
\hline Panax spp. (Ginseng) & Ginsenoside K & $\begin{array}{l}\text { Promotion of macrophage } \\
\text { and foam cell apoptosis }\end{array}$ & $\begin{array}{l}\text { (Reduction of foam } \\
\text { cell formation) } \\
1.25 \mu \mathrm{g} / \mathrm{mL}\end{array}$ & {$[86]$} \\
\hline Unspecified & Lupeol & $\begin{array}{l}\text { Promotion of macrophage } \\
\text { development into the M2 } \\
\text { anti-inflammatory } \\
\text { phenotype }\end{array}$ & $\begin{array}{c}\text { (Proinflammatory } \\
\text { cytokine secretion, } \\
\text { inh) } \\
\text { active at } 50 \mu \mathrm{M}\end{array}$ & [87] \\
\hline Tripterygium Wilfordi & Cerastrol & Action as leptin sensitizer & $\begin{array}{l}\text { (Leptin sensitization) } \\
\text { active at } 150 \mu \mathrm{g} / \mathrm{kg}\end{array}$ & {$[88]$} \\
\hline
\end{tabular}

Acalypha fluticosa extracts were recently screened for PPAR agonism and anti-inflammatory properties. Following a preliminary screening, four compounds were isolated from the methanol extract, namely 2-methyl-5,7-dihydroxychromone-5-O-b-D-glucopyranosid, acalyphin, apigenin, and kaempferol-3-O-rutinoside. Moreover, an acetylated derivate of chromone glucoside was synthesized and tested. In vitro on human hepatoma (HepG2) cells, acalyphin exhibited a specific PPAR $\gamma$ agonist activity, while apigenin revealed a weak PPAR $\alpha$ agonism. Chromone glucoside displayed activity as a dual PPAR $\alpha / \gamma$ agonist, while its acetylated derivative showed increased activity towards PPAR $\alpha$. These molecules, in particular acalyphin, also had anti-inflammatory properties, probably due to the inhibition of NF- $\mathrm{kB}$ and/or iNOS. Importantly, tested extracts and compounds were not found to be cytotoxic in vitro against human cells [70].

The ethanolic extract of stems of the Panamanian plant Talisia nervosa was also studied, along with its isolated components, for potential use in metabolic disorders. The extract displayed dual PPAR $\alpha / \gamma$ agonism and also increased liver $X$ receptor (LXR) activation. Therefore, four secondary metabolites, namely (-)-catechin, methyl gallate, ethyl gallate, and $\beta$-D-glucopyranose-1,4,6-tris(3,4,5-trihydroxybenzoate) were isolated and characterized. In vitro assays on HepG2 revealed that while (-)-catechin activated only PPAR $\gamma$ and not PPAR $\alpha$, the other three compounds activated PPAR $\alpha, \operatorname{PPAR} \gamma$ and LXR, with methyl gallate being more potent than ethyl gallate on all three targets. The two gallates also reduced nitric oxide (NO) production in mouse macrophages (RAW 264.7) cells [71].

Aside from five known bile acids, a new bile acid trifluoroacetate was isolated from jellyfish-derived fungus Penicillium chrysogenum J08NF-4. Its chemical structure and mechanism of action were similar to those of synthetic steroid mifepristone, which is clinically 
used for the treatment of hypercholesterolemia and recently turned out to be a PPAR $\gamma$ agonist. Docking studies confirmed that this new bile acid, like mifepristone, is capable of binding the ligand binding domain (LBD) of PPAR $\gamma$, thus suppressing the NF-kB pathway and downregulating the pro-inflammatory mediators iNOS, TNF- $\alpha$, and NO, with generalized anti-inflammatory effects, as confirmed by in vitro assay on LPS-induced RAW 264.7 macrophages [72].

Other than plants and fungi, marine cyanobacteria have been a promising source of secondary metabolites with potential medicinal use. As an example, chlorophyll derivatives $13^{2}$-hydroxy-pheopytin-a and the novel $13^{2}$-hydroxy-pheofarnesin-a were recently isolated from Cyanobium sp. LEGE 07,175 -and Nodosilinea sp. LEGE 06001, respectively. The zebrafish Nile red fat metabolism assay confirmed a neutral lipid-reducing activity of both compounds after $48 \mathrm{~h}$ of exposure, with no toxic effects. In order to explain the biological mechanism behind this activity profile, $13^{2}$-hydroxy-pheopytin-a was found to increase PPAR $\gamma$ mRNA expression. In light of these data, the presence of this compound in several foods, such as spinach, cabbage, Spirulina and Chlorella, makes it an important nutraceutical agent [73].

\subsection{Diabetes}

Type 2 diabetes (T2DM, or non-insulin dependent diabetes mellitus) is the most common form of diabetes. It is characterized by peripheric insulin resistance and hyperglycemia, leading to a loss of pancreatic $\beta$-cells which further exacerbates the pathology. No cure is currently available for this disease, however, various drugs capable of ameliorating the patients' quality of life and useful to control the disease have been approved [89]. Studies confirmed that natural products can also be used for the prevention and/or treatment of type 2 diabetes [90].

The therapy of T2DM usually focuses on reducing postprandial glycemia, restoring peripheric insulin sensitivity and improving $\beta$-cell survival. Other than the previously discussed PPAR $\gamma$, molecular targets for the therapy of T2DM include intestinal $\alpha$-glucosidase and pancreatic $\alpha$-amylase [91], which catalyze the hydrolysis of dietary carbohydrates and whose inhibition leads to decrease of postprandial blood glucose levels, thanks to a decreased digestion and uptake of carbohydrates [86]. Dipeptidyl peptidase-4 (DPP-4) is another target for the treatment of this pathology: this enzyme metabolizes glucagonlike peptide-1 (GLP-1), an incretin hormone which stimulates insulin secretion, inhibits glucagon secretion and delays gastric emptying [92]. Moreover, recent studies have proven the role of enzyme protein tyrosine phosphatase 1B (PTP1B) in the negative regulation of insulin signaling, making it a novel target for the treatment of T2DM [93].

An acidic polysaccharide from Schisandra chinensis (SCAP) was recently evaluated as a potential therapeutic agent in the streptozotocin-induced mouse model of diabetes. SCAP led to increased levels of fasting blood insulin and superoxide dismutase and to decreased levels of fasting blood glucose and malondialdehyde. This polysaccharide also prevented apoptosis of pancreatic $\beta$-cells through the up-regulation of factors such as BAX and Bcl-2, suggesting a possible mechanism for its antidiabetic activity. [75].

In another recent study, fourteen known compounds were isolated from S. grandiflora crude extract and tested against $\alpha$-amylase and $\alpha$-glucosidase in vitro. Two flavonoids (quercetin and kaempferol) and two terpenoids (vomifoliol and loliolide) showed inhibitory activity toward these enzymes, which was justified through docking studies. Finally, all bioactive molecules acted as antioxidants in the ABTS (2,2' -azino-bis(3-ethylbenzothiazoline6-sulfonic acid) radical scavenging assay. Quantitative analysis highlighted high concentrations of the most active compounds in the plant extract, suggesting a potential use of the edible S. grandiflora for the control of postprandial blood glucose in diabetic patients [76].

Similarly, flavonoids kaempferol-3-O-rhamnoside and kaempferol, isolated from Cassia bakeriana (pink cassia) extracts, were also recently studied for their antidiabetic activities. While kaempferol was unambiguously able to inhibit $\alpha$-amylase, the evaluation of the antioxidant activities of these compounds led to somewhat contrasting results, with both 
being active when tested via oxygen radical absorbance capacity (ORAC) method, and only kaempferol-3-O-rhamnoside being active in DPPH assay. It is worth noting that the isolated compounds are less active than the whole extract, suggesting the importance of synergic effects between the various components of the extract [77].

The leaf infusion of Ocimum campechianum (or wild basil) was reported to play an antidiabetic role through $\alpha$-glucosidase inhibition. Five poly-methoxylated flavones were isolated and their structures were elucidated, with two of these compounds (methyl rosmarinate and rosmarinic acid) displaying strong inhibition of $\alpha$-glucosidase in vitro and a marked decrease of blood glucose in vivo [78].

Natural compound stella-steroid was instead isolated from fungal plant pathogen Ganoderma australe, and its structure was elucidated via NMR spectroscopy. This compound showed inhibitory activity towards DPP- 4 and $\alpha$-glucosidase in silico and in vitro, with higher activity toward the latter target [80].

Two natural compounds from Aspergillus terreus, known as butyrolactone I and II, along with three synthetic acetylated derivatives of butyrolactone I, were also screened in a different study for their activity as $\alpha$-glucosidase inhibitors and as antioxidants. Butyrolactone I showed both $\alpha$-glucosidase inhibitory and antioxidant activities, while butyrolactone II was the most potent antioxidant compound, but had a lower inhibitory activity toward $\alpha$-glucosidase. Synthetic derivatives were less active, probably because of the acetylation of the hydroxyl groups of butyrolactone I [79].

Another fungus from the Aspergillus genus, Aspergillus sydowii, was found to produce a compound with significant antidiabetic potential, asperentin B. In vitro, this compound inhibited PTP1B six times more strongly than the positive control suramin. Interestingly, the structurally related compound asperentin did not display any inhibitory activity towards PTP1B. Future studies on structure-activity relationships and chemical modifications will be necessary to explain and enhance the antidiabetic activity of asperentin B [81].

\subsection{Obesity}

Obesity and overweight, defined as excess body weight, affect a growing number of adults, children and adolescents. Obesity in particular is often associated with the development of other disorders such as T2DM, cardiovascular disease and nonalcoholic fatty liver disease. Behavioral interventions, including dietary changes and increased physical exercise, are important to prevent obesity and to induce weight loss, however pharmacological treatment is often necessary in obese patients [94-96].

A viable strategy for the treatment of metabolic disorders like obesity is decreasing the absorption of dietary components such as fats and carbohydrates through the inhibition of metabolic enzymes, including lipase and, again, $\alpha$-glucosidase [97]. On the other hand, it is also necessary to act on signaling pathways that might be dysregulated as a result of obesity. Leptin is a protein involved in one such pathway; it is expressed in the adipocytes and it controls body weight and the mass of adipose tissue through the inhibition of food intake and the stimulation of energy expenditure. Defects in leptin production cause severe obesity [98].

A growing body of literature demonstrates the potential anti-obesity action of natural bioactive compounds, mostly derived from plants [99]. As an example, extracts from seeds and leaves Moringa oleifera were recently tested for various properties such as antioxidant, anti-inflammatory and anti-hyperlipidemic effects. Two sulfur-containing compounds were isolated from these extracts and were evaluated for their anti-adipogenic activity on pre-adipocyte 3T3-L1 cell line. One compound had no significant anti-adipogenic activity, while the other one showed a significant inhibition of intracellular lipid accumulation, probably due to the presence of an isothiocyanate group (ITC) in its structure. For this reason, a series of ITC derivatives were prepared, and most of them also showed anti-adipogenic activity [82]. Similarly, three eugenol diglycosides and three $\beta$-carboline alkaloids isolated from Garlic (Allium sativum L.) were screened on 3T3-L1 cells for their effects on adipogenesis and lipid metabolism. Among them, one $\beta$-carboline alkaloid inhib- 
ited adipogenesis and lipid accumulation through the regulation of adipogenic, lipogenic and lipolytic genes [83].

In another recent study, two natural labdane diterpenes and a drimane sesquiterpene were isolated from the hexane extract of Curcuma amada and they were tested for their inhibitory activity against rat intestinal $\alpha$-glucosidase and porcine pancreatic lipase. One of the two diterpenes showed relevant inhibitory activity toward both enzymes. Therefore, some semi-synthetic derivatives of this molecule were prepared and screened: a reduced derivative maintained $\alpha$-glucosidase inhibitory activity, while it lost lipase inhibition. At the opposite end of the spectrum, oxidized and acetate derivatives acted as good lipase inhibitors but had a weak $\alpha$-glucosidase inhibitory activity [84].

Another terpene, specifically a pentacyclic triterpene from the roots of Tripterygium Wilfordi, was recently discovered to be a leptin sensitizer. In hyperleptinemic diet-induced obese (DIO) mice it led to effects such as a significant decrease of food intake, increased hypothalamic leptin sensitivity, and weight loss, a promising profile for the treatment of obesity [88].

\subsection{Hypertension and Hyperinflammation-Managing Cardiowascular Risk in Metabolic Syndrome}

Hypertension and hyperinflammation are another important component of MS which, along with hypercholesterolemia, cause atherosclerosis and therefore significantly raise the cardiovascular risk linked to this syndrome [55].

In this case, too, secondary metabolites of plants and fungi have shown promise as preventative or therapeutic agents. As an example, honokiol, a natural compound from magnolia plants, was very recently shown to ameliorate Angiotensin II-induced hypertension and endothelial dysfunction via inhibition of histone deacetylase 6 (HDAC6) [85].

A very promising way to prevent cardiovascular risk related to hyperinflammation and atherosclerosis is to target the macrophages that accumulate in the site of the atherogenic lesion and bind low density lipoprotein (LDL), transforming in foam cells and driving inflammation further [100]. An aqueous bark extract from the plant Terminalia Arjuna, containing a number of polyphenols including gallic acid, epigallocatechin gallate and ellagic acid, displayed significant activity in stimulating apoptosis in macrophages and foam cells during the early stages of atherogenesis, thereby driving back inflammation and potentially reducing cardiovascular risk [101]. Similar effects were shown by ginseng-derived compound ginsenoside K [86], while lupeol, a pentacyclic terpene which can be found in a variety of fruits and vegetables, including mango, red grapes and tomato, was shown to be capable of shunting macrophage development towards the anti-inflammatory, reparative M2 phenotype (as opposed to the pro-inflammatory M1 phenotype) [87].

The formation of advanced-end glycation products (AGEs) is involved in several pathologies such as atherosclerosis, arterial stiffness, but also Parkinson's disease and Alzheimer's disease. In a recent study, a group of lichen secondary metabolites and one semisynthetic derivative were shown to possess relevant inhibitory activity towards AGE formation. Although some of these compounds were endowed with antioxidant activity, it was not necessarily linked to the inhibition of AGE formation. Moreover, the tested compounds proved to have vasodilative effects, potentially useful in alleviating hypertension linked to atherosclerosis [74].

Finally, three new alkaloids (communesin $\mathrm{I}$, fumoquinazoline $\mathrm{Q}$ and protuboxepin E) and nine known alkaloids (communesin A and B, cottoquinazoline A, prelapatin B, glyantrypine, protuboxepin $\mathrm{A}$ and $\mathrm{B}$, chaetoglobosin $\mathrm{C}$ and penochalasin $\mathrm{E}$ ) were recently isolated from the marine-derived fungus Penicillium expansum Y32. All molecules were screened in vivo on a zebrafish model for their cardiovascular effects. All of them exhibited a mitigative activity on bradycardia induced by astemizole; moreover, all compounds, except for communesin B, showed vasculo-genetic effects [58]. 


\section{Conclusions}

The research reviewed in this paper confirms the rising importance of natural compounds in the inspiration of new therapeutic protocols for the prevention and/or treatment of chronic diseases.

However, the use of secondary metabolites requires in many cases a specific formulation, when we consider that they are often insoluble in water, and the problems related to the abuse of supplements containing bioactive molecules, while outside the scope of this review, must still be carefully considered, taking into account the side effects of the active ingredients themselves and the possibility of external contamination [102]. The already mentioned case of Monacolin K, a blockbuster product which presents the same problems as statins (being a statin itself) and a high possibility of contamination with citrinin (fermented red rice with Monascus Purpureus strains is the only regulated matrix in EU for this mycotoxin [103]), must be a wake-up call to the food supplement industry. Therefore, future research must definitely focus on the analysis of natural contaminants such as ochratoxin A [104] and other mycotoxins, as well as residues of pesticides and heavy metals, if these bioactive compounds are to be included in plant food supplements [105].

The design of new potential drugs starting from the structures of natural compounds and the preparation of these molecules with a semi-synthetic or a total-synthetic approach will be another significant challenge in future years. Several research groups are working on this fascinating, though not always linear, route $[72,82,106]$, and important results are expected.

Author Contributions: L.P. performed the bibliographic research and wrote the manuscript along with L.B., V.P. and R.L. L.B., A.L., F.L., P.T. and L.P. provided helpful discussions and revised the manuscript. All authors have read and agreed to the published version of the manuscript.

Funding: This research received no external funding.

Acknowledgments: The authors would like to thank Nicoletta Gadaleta for providing the picture in the graphical abstract.

Conflicts of Interest: The authors declare no conflict of interest.

\section{References}

1. Salem, M.A.; De Souza, L.P.; Serag, A.; Fernie, A.R.; Farag, M.A.; Ezzat, S.M.; Alseekh, S. Metabolomics in the context of plant natural products research: From sample preparation to metabolite analysis. Metabolites 2020, 10, 37. [CrossRef] [PubMed]

2. Wink, M. Modes of Action of Herbal Medicines and Plant Secondary Metabolites. Medicines 2015, 2, 251-286. [CrossRef] [PubMed]

3. Seca, A.; Pinto, D. Plant Secondary Metabolites as Anticancer Agents: Successes in Clinical Trials and Therapeutic Application. Int. J. Mol. Sci. 2018, 19, 263. [CrossRef] [PubMed]

4. Saloustros, E.; Mavroudis, D.; Georgoulias, V. Paclitaxel and docetaxel in the treatment of breast cancer. Expert Opin. Pharmacother. 2008, 9, 2603-2616. [CrossRef]

5. Kumar, A. Vincristine and vinblastine: A review. Int. J. Med. Pharm. Sci. 2016, 6, 23-30.

6. Vacca, R.A.; Valenti, D.; Caccamese, S.; Daglia, M.; Braidy, N.; Nabavi, S.M. Plant polyphenols as natural drugs for the management of Down syndrome and related disorders. Neurosci. Biobehav. Rev. 2016, 71, 865-877. [CrossRef]

7. Shahidi, F.; Yeo, J.D. Bioactivities of phenolics by focusing on suppression of chronic diseases: A review. Int. J. Mol. Sci. 2018, 19, 1573. [CrossRef]

8. Huang, X.-T.; Li, X.; Xie, M.-L.; Huang, Z.; Huang, Y.-X.; Wu, G.-X.; Peng, Z.-R.; Sun, Y.-N.; Ming, Q.-L.; Liu, Y.-X.; et al. Resveratrol: Review on its discovery, anti-leukemia effects and pharmacokinetics. Chem. Biol. Interactions 2019, 306, 29-38. [CrossRef]

9. Gonçalves, J.; Rosado, T.; Soares, S.; Simão, A.; Caramelo, D.; Luís, Â.; Fernández, N.; Barroso, M.; Gallardo, E.; Duarte, A. Cannabis and Its Secondary Metabolites: Their Use as Therapeutic Drugs, Toxicological Aspects, and Analytical Determination. Medicines 2019, 6, 31. [CrossRef]

10. Bonini, S.A.; Premoli, M.; Tambaro, S.; Kumar, A.; Maccarinelli, G.; Memo, M.; Mastinu, A. Cannabis sativa: A comprehensive ethnopharmacological review of a medicinal plant with a long history. J. Ethnopharmacol. 2018, 227, 300-315. [CrossRef]

11. Misiek, M.; Hoffmeister, D. Fungal genetics, genomics, and secondary metabolites in pharmaceutical sciences. Planta Med. 2007, 73, 103-115. [CrossRef] [PubMed]

12. Tahlan, K.; Jensen, S.E. Origins of the $\beta$-lactam rings in natural products. J. Antibiot. 2013, 66, 401-410. [CrossRef] [PubMed]

13. Ho, V.C. The use of ciclosporin in psoriasis: A clinical review. Br. J. Dermatol. Suppl. 2004, 150, 1-10. [CrossRef] [PubMed] 
14. Leuci, R.; Brunetti, L.; Laghezza, A.; Tortorella, P.; Loiodice, F.; Piemontese, L. A Review of Recent Patents (2016-2019) on Plant Food Supplements with Potential Application in the Treatment of Neurodegenerative and Metabolic Disorders. Recent Pat. Food. Nutr. Agric. 2020, 11, 145-153. [CrossRef]

15. Journoud, M.; Jones, P.J.H. Red yeast rice: A new hypolipidemic drug. Life Sci. 2004, 74, 2675-2683. [CrossRef]

16. Brunetti, L.; Laghezza, A.; Loiodice, F.; Tortorella, P.; Piemontese, L. Combining fatty acid amide hydrolase (FAAH) inhibition with peroxisome proliferator-activated receptor (PPAR) activation: A new potential multi-target therapeutic strategy for the treatment of Alzheimer's disease. Neural Regen. Res. 2020, 15, 67-68. [CrossRef]

17. Fancellu, G.; Chand, K.; Tomás, D.; Orlandini, E.; Piemontese, L.; Silva, D.F.; Cardoso, S.M.; Chaves, S.; Santos, M.A. Novel tacrine-benzofuran hybrids as potential multi-target drug candidates for the treatment of Alzheimer's Disease. J. Enzym. Inhib. Med. Chem. 2020, 35, 211-226. [CrossRef]

18. Piemontese, L.; Loiodice, F.; Chaves, S.; Santos, M.A. The Therapy of Alzheimer's Disease: Towards a New Generation of Drugs. Front. Clin. Drug Res. Alzheimer Disord. 2019, 8, 33-80. [CrossRef]

19. Popa-Wagner, A.; Dumitrascu, D.; Capitanescu, B.; Petcu, E.; Surugiu, R.; Fang, W.-H.; Dumbrava, D.-A. Dietary habits, lifestyle factors and neurodegenerative diseases. Neural Regen. Res. 2020, 15, 394-400. [CrossRef]

20. Fernández-Moriano, C.; Divakar, P.K.; Crespo, A.; Gómez-Serranillos, M.P. In vitro neuroprotective potential of lichen metabolite fumarprotocetraric acid via intracellular redox modulation. Toxicol. Appl. Pharmacol. 2017, 316, 83-94. [CrossRef]

21. Leirós, M.; Sánchez, J.A.; Alonso, E.; Rateb, M.E.; Houssen, W.E.; Ebel, R.; Jaspars, M.; Alfonso, A.; Botana, L.M. Spongionella secondary metabolites protect mitochondrial function in cortical neurons against oxidative stress. Mar. Drugs 2014, 12, 700-718. [CrossRef] [PubMed]

22. Gugnani, K.S.; Vu, N.; Rondón-Ortiz, A.N.; Böhlke, M.; Maher, T.J.; Pino-Figueroa, A.J. Neuroprotective activity of macamides on manganese-induced mitochondrial disruption in U-87 MG glioblastoma cells. Toxicol. Appl. Pharmacol. 2018, 340, 67-76. [CrossRef] [PubMed]

23. Yang, L.H.; Ou-Yang, H.; Yan, X.; Tang, B.W.; Fang, M.J.; Wu, Z.; Chen, J.W.; Qiu, Y.K. Open-ring butenolides from a marinederived anti-neuroinflammatory fungus aspergillus terreus Y10. Mar. Drugs 2018, 16, 428. [CrossRef] [PubMed]

24. Badria, F.A.; Guirguis, A.N.; Perovic, S.; Steffen, R.; Müller, W.E.G.; Schröder, H.C. Sarcophytolide: A new neuroprotective compound from the soft coral Sarcophyton glaucum. Toxicology 1998, 131, 133-143. [CrossRef]

25. Rupcic, Z.; Rascher, M.; Kanaki, S.; Köster, R.W.; Stadler, M.; Wittstein, K. Two new cyathane diterpenoids from mycelial cultures of the medicinal mushroom hericium erinaceus and the rare species, hericium flagellum. Int. J. Mol. Sci. 2018, 19, 740. [CrossRef] [PubMed]

26. Karakoyun, Ç.; Bozkurt, B.; Çoban, G.; Masi, M.; Cimmino, A.; Evidente, A.; Somer, N.U. A comprehensive study on narcissus tazetta subsp. tazetta L.: Chemo-profiling, isolation, anticholinesterase activity and molecular docking of amaryllidaceae alkaloids. S. Afr. J. Bot. 2020, 130, 148-154. [CrossRef]

27. Nuthakki, V.K.; Sharma, A.; Kumar, A.; Bharate, S.B. Identification of embelin, a 3-undecyl-1,4-benzoquinone from Embelia ribes as a multitargeted anti-Alzheimer agent. Drug Dev. Res. 2019, 80, ddr.21544. [CrossRef]

28. Augustin, N.; Nuthakki, V.K.; Abdullaha, M.; Hassan, Q.P.; Gandhi, S.G.; Bharate, S.B. Discovery of Helminthosporin, an Anthraquinone Isolated from Rumex abyssinicus Jacq as a Dual Cholinesterase Inhibitor. ACS Omega 2020, 5, 1616-1624. [CrossRef]

29. Imran, M.; Irfan, A.; Ibrahim, M.; Assiri, M.A.; Khalid, N.; Ullah, S.; Al-Sehemi, A.G. Carbonic anhydrase and cholinesterase inhibitory activities of isolated flavonoids from Oxalis corniculata L. and their first-principles investigations. Ind. Crops Prod. 2020, 148, 112285. [CrossRef]

30. Reddy, R.G.; Veeraval, L.; Maitra, S.; Chollet-Krugler, M.; Tomasi, S.; Dévéhat, F.L.L.; Boustie, J.; Chakravarty, S. Lichen-derived compounds show potential for central nervous system therapeutics. Phytomedicine 2016, 23, 1527-1534. [CrossRef]

31. Piemontese, L.; Vitucci, G.; Catto, M.; Laghezza, A.; Perna, F.M.; Rullo, M.; Loiodice, F.; Capriati, V.; Solfrizzo, M. Natural scaffolds with multi-target activity for the potential treatment of Alzheimer's disease. Molecules 2018, 23, 2182. [CrossRef] [PubMed]

32. Lee, H.W.; Ryu, H.W.; Kang, M.G.; Park, D.; Oh, S.R.; Kim, H. Potent selective monoamine oxidase B inhibition by maackiain, a pterocarpan from the roots of Sophora flavescens. Bioorganic Med. Chem. Lett. 2016, 26, 4714-4719. [CrossRef] [PubMed]

33. Chaurasiya, N.D.; León, F.; Ding, Y.; Gómez-Betancur, I.; Benjumea, D.; Walker, L.A.; Cutler, S.J.; Tekwani, B.L. Interactions of Desmethoxyyangonin, a Secondary Metabolite from Renealmia alpinia, with Human Monoamine Oxidase-A and Oxidase-B. Evid. Based Complement. Altern. Med. 2017, 2017, 4018724. [CrossRef] [PubMed]

34. Vijayakumaran, S.; Nakamura, Y.; Henley, J.M.; Pountney, D.L. Ginkgolic acid promotes autophagy-dependent clearance of intracellular alpha-synuclein aggregates. Mol. Cell. Neurosci. 2019, 101, 103416. [CrossRef]

35. Jia, L.; Wang, Y.; Sang, J.; Cui, W.; Zhao, W.; Wei, W.; Chen, B.; Lu, F.; Liu, F. Dihydromyricetin Inhibits $\alpha$-Synuclein Aggregation, Disrupts Preformed Fibrils, and Protects Neuronal Cells in Culture against Amyloid-Induced Cytotoxicity. J. Agric. Food Chem. 2019, 67, 3946-3955. [CrossRef] [PubMed]

36. Hsieh, H.L.; Yang, C.M. Role of redox signaling in neuroinflammation and neurodegenerative diseases. Biomed Res. Int. 2013, 2013, 484613. [CrossRef] [PubMed]

37. Albarracin, S.L.; Stab, B.; Casas, Z.; Sutachan, J.J.; Samudio, I.; Gonzalez, J.; Gonzalo, L.; Capani, F.; Morales, L.; Barreto, G.E. Effects of natural antioxidants in neurodegenerative disease. Nutr. Neurosci. 2012, 15, 1-9. [CrossRef] [PubMed] 
38. Basavarajappa, B.S.; Shivakumar, M.; Joshi, V.; Subbanna, S. Endocannabinoid system in neurodegenerative disorders. J. Neurochem. 2017, 142, 624-648. [CrossRef]

39. González, J.F.; Alcántara, A.R.; Doadrio, A.L.; Sánchez-Montero, J.M. Developments with multi-target drugs for Alzheimer's disease: An overview of the current discovery approaches. Expert Opin. Drug Discov. 2019, 14, 879-891. [CrossRef]

40. Mendez, M.F. Early-onset Alzheimer disease and its variants. Continuum 2019, 25, 34-51. [CrossRef]

41. Du, X.; Wang, X.; Geng, M. Alzheimer's disease hypothesis and related therapies. Transl. Neurodegener. 2018, 7, 2. [CrossRef] [PubMed]

42. Baig, M.H.; Ahmad, K.; Rabbani, G.; Choi, I. Use of Peptides for the Management of Alzheimer's Disease: Diagnosis and Inhibition. Front. Aging Neurosci. 2018, 10, 21. [CrossRef] [PubMed]

43. Martorana, A.; Esposito, Z.; Koch, G. Beyond the Cholinergic Hypothesis: Do Current Drugs Work in Alzheimer's Disease? CNS Neurosci. Ther. 2010, 16, 235-245. [CrossRef] [PubMed]

44. Harvey, A.L. The pharmacology of galanthamine and its analogues. Pharmacol. Ther. 1995, 68, 113-128. [CrossRef]

45. Jankovic, J. Parkinson's disease: Clinical features and diagnosis. J. Neurol. Neurosurg. Psychiatry 2008, 79, 368-376. [CrossRef]

46. Park, J.S.; Leem, Y.H.; Park, J.E.; Kim, D.Y.; Kim, H.S. Neuroprotective effect of $\beta$-lapachone in MPTP-induced parkinson's disease mouse model: Involvement of astroglial p-AMPK/Nrf2/HO-1 signaling pathways. Biomol. Ther. 2019, 27, 178-184. [CrossRef]

47. Gazewood, J.D.; Richards, D.R.; Clebak, K. Parkinson Disease: An Update. Am. Fam. Physician 2013, 87, $267-273$.

48. Kumar, B.; Sheetal, S.; Mantha, A.K.; Kumar, V. Recent developments on the structure-activity relationship studies of MAO inhibitors and their role in different neurological disorders. RSC Adv. 2016, 6, 42660-42683. [CrossRef]

49. Fernandez, H.H.; Chen, J.J. Monoamine oxidase-B inhibition in the treatment of Parkinson's disease. Pharmacotherapy 2007, 27, 174S-185S. [CrossRef]

50. Finberg, J.P.M. Update on the pharmacology of selective inhibitors of MAO-A and MAO-B: Focus on modulation of CNS monoamine neurotransmitter release. Pharmacol. Ther. 2014, 143, 133-152. [CrossRef]

51. Carradori, S.; Gidaro, M.C.; Petzer, A.; Costa, G.; Guglielmi, P.; Chimenti, P.; Alcaro, S.; Petzer, J.P. Inhibition of Human Monoamine Oxidase: Biological and Molecular Modeling Studies on Selected Natural Flavonoids. J. Agric. Food Chem. 2016, 64, 9004-9011. [CrossRef] [PubMed]

52. Stefanis, L. $\alpha$-Synuclein in Parkinson's disease. Cold Spring Harb. Perspect. Med. 2012, 2, a009399. [CrossRef] [PubMed]

53. Recchia, A.; Debetto, P.; Negro, A.; Guidolin, D.; Skaper, S.D.; Giusti, P. $\alpha$-Synuclein and Parkinson's disease. FASEB J. 2004, 18, 617-626. [CrossRef]

54. Liu, H.; Ye, M.; Guo, H. An Updated Review of Randomized Clinical Trials Testing the Improvement of Cognitive Function of Ginkgo biloba Extract in Healthy People and Alzheimer's Patients. Front Pharmacol. 2019, 10, 1688. [CrossRef] [PubMed]

55. Eckel, R.H.; Grundy, S.M.; Zimmet, P.Z. The metabolic syndrome. Lancet 2005, 365, 1415-1428. [CrossRef]

56. Ritchie, S.A.; Connell, J.M.C. The link between abdominal obesity, metabolic syndrome and cardiovascular disease. Nutr. Metab. Cardiovasc. Dis. 2007, 17, 319-326. [CrossRef]

57. Luna-Vázquez, F.J.; Ibarra-Alvarado, C.; Rojas-Molina, A.; Rojas-Molina, I.; Zavala-Sánchez, M.Á. Vasodilator compounds derived from plants and their mechanisms of action. Molecules 2013, 18, 5814-5857. [CrossRef]

58. Fan, Y.Q.; Li, P.H.; Chao, Y.X.; Chen, H.; Du, N.; He, Q.X.; Liu, K.C. Alkaloids with cardiovascular effects from the marine-derived fungus Penicillium expansum Y32. Mar. Drugs 2015, 13, 6489-6504. [CrossRef]

59. Saklayen, M.G. The Global Epidemic of the Metabolic Syndrome. Curr. Hypertens. Rep. 2018, 20, 12. [CrossRef]

60. Carrieri, A.; Giudici, M.; Parente, M.; De Rosas, M.; Piemontese, L.; Fracchiolla, G.; Laghezza, A.; Tortorella, P.; Carbonara, G.; Lavecchia, A.; et al. Molecular determinants for nuclear receptors selectivity: Chemometric analysis, dockings and site-directed mutagenesis of dual peroxisome proliferator-activated receptors $\alpha / \gamma$ agonists. Eur. J. Med. Chem. 2013, 63, 321-332. [CrossRef]

61. Laghezza, A.; Piemontese, L.; Cerchia, C.; Montanari, R.; Capelli, D.; Giudici, M.; Crestani, M.; Tortorella, P.; Peiretti, F.; Pochetti, G.; et al. Identification of the First PPAR $\alpha / \gamma$ Dual Agonist Able to Bind to Canonical and Alternative Sites of PPAR $\gamma$ and to Inhibit Its Cdk5-Mediated Phosphorylation. J. Med. Chem. 2018, 61, 8282-8298. [CrossRef]

62. Schoonjans, K.; Staels, B.; Auwerx, J. Role of the peroxisome proliferator-activated receptor (PPAR) in mediating the effects of fibrates and fatty acids on gene expression. J. Lipid Res. 1996, 37, 907-925. [PubMed]

63. Michalik, L.; Wahli, W. Peroxisome proliferator-activated receptors: Three isotypes for a multitude of functions. Curr. Opin. Biotechnol. 1999, 10, 564-570. [CrossRef]

64. Piemontese, L.; Fracchiolla, G.; Carrieri, A.; Parente, M.; Laghezza, A.; Carbonara, G.; Sblano, S.; Tauro, M.; Gilardi, F.; Tortorella, P.; et al. Design, synthesis and biological evaluation of a class of bioisosteric oximes of the novel dual peroxisome proliferatoractivated receptor $\alpha / \gamma$ ligand LT175. Eur. J. Med. Chem. 2015, 90, 583-594. [CrossRef]

65. Lamichane, S.; Dahal Lamichane, B.; Kwon, S.-M. Pivotal Roles of Peroxisome Proliferator-Activated Receptors (PPARs) and Their Signal Cascade for Cellular and Whole-Body Energy Homeostasis. Int. J. Mol. Sci. 2018, 19, 949. [CrossRef]

66. Penumetcha, M.; Santanam, N. Nutraceuticals as ligands of PPAR $\gamma$. PPAR Res. 2012, 2012, 858352. [CrossRef] [PubMed]

67. Fracchiolla, G.; Lavecchia, A.; Laghezza, A.; Piemontese, L.; Trisolini, R.; Carbonara, G.; Tortorella, P.; Novellino, E.; Loiodice, F. Synthesis, biological evaluation, and molecular modeling investigation of chiral 2-(4-chloro-phenoxy)-3-phenyl-propanoic acid derivatives with PPAR $\alpha$ and PPAR $\gamma$ agonist activity. Bioorganic Med. Chem. 2008, 16, 9498-9510. [CrossRef] 
68. Fracchiolla, G.; Laghezza, A.; Piemontese, L.; Parente, M.; Lavecchia, A.; Pochetti, G.; Montanari, R.; Di Giovanni, C.; Carbonara, G.; Tortorella, P.; et al. Synthesis, biological evaluation and molecular investigation of fluorinated peroxisome proliferatoractivated receptors $\alpha / \gamma$ dual agonists. Bioorganic Med. Chem. 2012, 20, 2141-2151. [CrossRef]

69. Laghezza, A.; Montanari, R.; Lavecchia, A.; Piemontese, L.; Pochetti, G.; Iacobazzi, V.; Infantino, V.; Capelli, D.; DeBellis, M.; Liantonio, A.; et al. On the Metabolically Active Form of Metaglidasen: Improved Synthesis and Investigation of Its Peculiar Activity on Peroxisome Proliferator-Activated Receptors and Skeletal Muscles. ChemMedChem 2015, 10, 555-565. [CrossRef]

70. Fawzy, G.A.; Al-Taweel, A.M.; Perveen, S.; Khan, S.I.; Al-Omary, F.A. Bioactivity and chemical characterization of Acalypha fruticosa Forssk. growing in Saudi Arabia. Saudi Pharm. J. 2017, 25, 104-109. [CrossRef]

71. Vásquez, Y.; Zhao, J.; Khana, S.I.; Gupta, M.P.; Khana, I.A. Constituents of talisia nervosa with potential utility against metabolic syndrome. Nat. Prod. Commun. 2019, 14, 51-54. [CrossRef]

72. Liu, S.; Wang, Y.; Su, M.; Song, S.J.; Hong, J.; Kim, S.; Im, D.S.; Jung, J.H. A bile acid derivative with PPAR $\gamma$-mediated anti-inflammatory activity. Steroids 2018, 137, 40-46. [CrossRef] [PubMed]

73. Freitas, S.; Silva, N.G.; Sousa, M.L.; Ribeiro, T.; Rosa, F.; Leão, P.N.; Vasconcelos, V.; Reis, M.A.; Urbatzka, R. Chlorophyll derivatives from marine cyanobacteria with lipid-reducing activities. Mar. Drugs 2019, 17, 229. [CrossRef] [PubMed]

74. Schinkovitz, A.; Le Pogam, P.; Derbré, S.; Roy-Vessieres, E.; Blanchard, P.; Thirumaran, S.L.; Breard, D.; Aumond, M.C.; Zehl, M.; Urban, E.; et al. Secondary metabolites from lichen as potent inhibitors of advanced glycation end products and vasodilative agents. Fitoterapia 2018, 131, 182-188. [CrossRef] [PubMed]

75. Tao, X.; Liang, S.; Che, J.Y.; Li, H.; Sun, H.X.; Chen, J.G.; Du, X.X.; Wang, C.M. Antidiabetic activity of acidic polysaccharide from schisandra chinensis in STZ-induced diabetic mice. Nat. Prod. Commun. 2019, 14, 1-9. [CrossRef]

76. Thissera, B.; Visvanathan, R.; Khanfar, M.A.; Qader, M.M.; Hassan, M.H.A.; Hassan, H.M.; Bawazeer, M.; Behery, F.A.; Yaseen, M.; Liyanage, R.; et al. Sesbania grandiflora L. Poir leaves: A dietary supplement to alleviate type 2 diabetes through metabolic enzymes inhibition. S. Afr. J. Bot. 2020, 130, 282-299. [CrossRef]

77. Silva, T.D.C.; Justino, A.B.; Prado, D.G.; Koch, G.A.; Martins, M.M.; Santos, P.D.S.; De Morais, S.A.L.; Goulart, L.R.; Cunha, L.C.S.; Sousa, R.M.F.; et al. Chemical composition, antioxidant activity and inhibitory capacity of $\alpha$-amylase, $\alpha$-glucosidase, lipase and non-enzymatic glycation, in vitro, of the leaves of Cassia bakeriana Craib. Ind. Crops Prod. 2019, 140, 111641. [CrossRef]

78. Ruiz-Vargas, J.A.; Morales-Ferra, D.L.; Ramírez-Ávila, G.; Zamilpa, A.; Negrete-León, E.; Acevedo-Fernández, J.J.; PeñaRodríguez, L.M. $\alpha$-Glucosidase inhibitory activity and in vivo antihyperglycemic effect of secondary metabolites from the leaf infusion of Ocimum campechianum mill. J. Ethnopharmacol. 2019, 243, 112081. [CrossRef]

79. Dewi, R.T.; Tachibana, S.; Darmawan, A. Effect on $\alpha$-glucosidase inhibition and antioxidant activities of butyrolactone derivatives from Aspergillus terreus MC751. Med. Chem. Res. 2014, 23, 454-460. [CrossRef]

80. Budipramana, K.; Junaidin, J.; Wirasutisna, K.R.; Pramana, Y.B.; Sukrasno, S. An integrated in silico and in vitro assays of dipeptidyl peptidase-4 and $\alpha$-glucosidase inhibition by stellasterol from Ganoderma australe. Sci. Pharm. 2019, 87, 21. [CrossRef]

81. Wiese, J.; Aldemir, H.; Schmaljohann, R.; Gulder, T.A.M.; Imhoff, J.F.; Kerr, R. Asperentin B, a new inhibitor of the protein tyrosine phosphatase 1B. Mar. Drugs 2017, 15, 191. [CrossRef] [PubMed]

82. Huang, L.; Yuan, C.; Wang, Y. Bioactivity-guided identification of anti-adipogenic isothiocyanates in the moringa (Moringa oleifera) seed and investigation of the structure-activity relationship. Molecules 2020, 25, 2504. [CrossRef] [PubMed]

83. Baek, S.C.; Nam, K.H.; Yi, S.A.; Jo, M.S.; Lee, K.H.; Lee, Y.H.; Lee, J.; Kim, K.H. Anti-adipogenic Effect of $\beta$-Carboline Alkaloids from Garlic (Allium sativum). Foods 2019, 8, 673. [CrossRef]

84. Yoshioka, Y.; Yoshimura, N.; Matsumura, S.; Wada, H.; Hoshino, M.; Makino, S.; Morimoto, M. $\alpha$-Glucosidase and pancreatic lipase inhibitory activities of diterpenes from indian mango ginger (curcuma amada roxb.) and its derivatives. Molecules 2019, 24, 4071. [CrossRef]

85. Chi, Z.; Le, T.P.H.; Lee, S.K.; Guo, E.; Kim, D.; Lee, S.; Seo, S.Y.; Lee, S.Y.; Kim, J.H.; Lee, S.Y. Honokiol ameliorates angiotensin II-induced hypertension and endothelial dysfunction by inhibiting HDAC6-mediated cystathionine $\gamma$-lyase degradation. J. Cell Mol. Med. 2020, 24, 10663-10676. [CrossRef]

86. Lu, S.; Luo, Y.; Sun, G.B.; Sun, X.B. Ginsenoside Compound K Attenuates Ox-LDL-Mediated Macrophage Inflammation and Foam Cell Formation via Autophagy Induction and Modulating NF-kB, p38, and JNK MAPK Signaling. Front. Pharmacol. 2020, 11, 567238. [CrossRef]

87. Saha, S.; Profumo, E.; Togna, A.R.; Riganò, R.; Saso, L.; Buttari, B. Lupeol Counteracts the Proinflammatory Signalling Triggered in Macrophages by 7-Keto-Cholesterol: New Perspectives in the Therapy of Atherosclerosis. Oxid. Med. Cell. Longev. 2020, 2020, 1-12. [CrossRef]

88. Liu, J.; Lee, J.; Hernandez, M.A.S.; Mazitschek, R.; Ozcan, U. Treatment of obesity with celastrol. Cell 2015, 161, 999-1011. [CrossRef]

89. Olokoba, A.B.; Obateru, O.A.; Olokoba, L.B. Type 2 diabetes mellitus: A review of current trends. Oman Med. J. 2012, 27, 269-273. [CrossRef]

90. Hays, N.P.; Galassetti, P.R.; Coker, R.H. Prevention and treatment of type 2 diabetes: Current role of lifestyle, natural product, and pharmacological interventions. Pharmacol. Ther. 2008, 118, 181-191. [CrossRef]

91. Salehi, P.; Asghari, B.; Esmaeili, M.A.; Dehghan, H.; Ghazi, I. -Glucosidase and -amylase inhibitory effect and antioxidant activity of ten plant extracts traditionally used in Iran for diabetes. J. Med. Plants Res. 2013, 7, 257-266. [CrossRef] 
92. Ahrén, B.; Schmitz, O. GLP-1 receptor agonists and DPP-4 inhibitors in the treatment of type 2 diabetes. Horm. Metab. Res. 2004, 36, 867-876. [CrossRef] [PubMed]

93. Montalibet, J.; Kennedy, B.P. Therapeutic strategies for targeting PTP1B in diabetes. Drug Discov. Today Ther. Strateg. 2005, 2, 129-135. [CrossRef]

94. Kopelman, P.G. Obesity as a medical problem. Nature 2000, 404, 635-643. [CrossRef] [PubMed]

95. Ogden, C.L.; Yanovski, S.Z.; Carroll, M.D.; Flegal, K.M. The Epidemiology of Obesity. Gastroenterology 2007, 132, 2087-2102. [CrossRef] [PubMed]

96. Hussain, S.S.; Bloom, S.R. The pharmacological treatment and management of obesity. Postgrad. Med. 2011, 123, 34-44. [CrossRef] [PubMed]

97. Mohapatra, S.; Prasad, A.; Haque, F.; Ray, S.; De, B.; Ray, S.S. In silico investigation of black tea components on $\alpha$-amylase, $\alpha$-glucosidase and lipase. J. Appl. Pharm. Sci. 2015, 5, 42-47. [CrossRef]

98. Paracchini, V.; Pedotti, P.; Taioli, E. Genetics of leptin and obesity: A HuGE review. Am. J. Epidemiol. 2005, 162, 101-114. [CrossRef]

99. Torres-Fuentes, C.; Schellekens, H.; Dinan, T.G.; Cryan, J.F. A natural solution for obesity: Bioactives for the prevention and treatment of weight gain. A review. Nutr. Neurosci. 2015, 18, 49-65. [CrossRef]

100. Libby, P.; Buring, J.E.; Badimon, L.; Hansson, G.K.; Deanfield, J.; Bittencourt, M.S.; Tokgözoğlu, L.; Lewis, E.F. Atherosclerosis. Nat. Rev. Dis. Prim. 2019, 5, 56. [CrossRef]

101. Bhansali, S.; Khatri, S.; Dhawan, V. Terminalia Arjuna bark extract impedes foam cell formation and promotes apoptosis in ox-LDL-stimulated macrophages by enhancing UPR-CHOP pathway. Lipids Health Dis. 2019, 18, 195. [CrossRef] [PubMed]

102. Piemontese, L. Plant Food Supplements with Antioxidant Properties for the Treatment of Chronic and Neurodegenerative Diseases: Benefits or Risks? J. Diet Suppl. 2017, 14, 478-484. [CrossRef] [PubMed]

103. Commission Regulation (EU) No 212/2014 of 6 March 2014. Amending Regulation (EC) No 1881/2006 as Regards Maximum Levels of the Contaminant Citrinin in Food Supplements based on Rice Fermented with Red Yeast Monascus purpureus (Text with EEA relevance); European Union: Brussels, Belgium, 2014.

104. Piemontese, L.; Perna, F.M.; Logrieco, A.; Capriati, V.; Solfrizzo, M. Deep eutectic solvents as novel and effective extraction media for quantitative determination of Ochratoxin A in wheat and derived products. Molecules 2017, 22, 121. [CrossRef] [PubMed]

105. Moncalvo, A.; Marinoni, L.; Dordoni, R.; Garrido, G.D.; Lavelli, V.; Spigno, G. Waste grape skins: Evaluation of safety aspects for the production of functional powders and extracts for the food sector. Food Addit. Contam. Part A Chem. Anal. Control. Exp. Risk Assess. 2016, 33, 1116-1126. [CrossRef] [PubMed]

106. Poliseno, V.; Chaves, S.; Brunetti, L.; Loiodice, F.; Carrieri, A.; Laghezza, A.; Tortorella, P.; Magalhaes, J.D.; Cardoso, S.M.; Santos, M.A.; et al. Derivatives of Tenuazonic Acid as Potential New Multi-Target Anti-Alzheimer's Disease Agents. Biomolecules 2021, 11, 111. [CrossRef] 